\title{
Impact of Basel Iii Regulations on Banks: Evidence from Afriland First Bank in Cameroon
}

\author{
TAN ZHONMING (PhD Professor) \\ Jiangsu University, School of Finance and Economics, Zhenjiang, China \\ GINETTE YANASSONG NKILI. \\ Overseas Education College, School of Finance and Economics, Jiangsu University, Zhenjiang, China \\ DING GUOPING \\ Overseas Education College, School of Finance and Economics, Jiangsu University, Zhenjiang, China \\ Ernest Kay Bakpa \\ Overseas Education College, School of Finance and Economics, Jiangsu University, Zhenjiang, China
}

\begin{abstract}
Bank financing is an engine of economic growth, mainly where financial intermediation is more advanced. The public authorities are therefore faced with the obligation to advocate for the resilience of the financial system. As part of their assignments, supervisors are working to put in place prudential regulation that would require banks to have a solid financial base to face the various risks and perils. Although the financial crisis has confirmed the need for adjustments in prudential regulation, the financial institutions have denounced the high cost of the new Basel requirements, a cost that would inevitably weigh on the banking activity and, consequently, on the economic activity. Based on this observation, we are conducting an impact study whose objective would is to evaluate and demonstrate the impact of the implementation of the Basel III agreements in Cameroon.
\end{abstract}

Keywords: Banking; Basel III regulations; solid financial base; financial institutions;

DOI: $10.7176 /$ RJFA/10-13-05

Publication date:July $31^{\text {st }} 2019$

\section{1- Introduction}

Banking regulations vary between jurisdictions. The banking system in Cameroon is regulated by laws and regulations whose sources are: International Conventions, Customs Laws, Ordinances, Presidential Decrees, Ministerial Orders, Circulars and Court Decisions. These regulatory instruments are flexible in character, meaning they can be a subject of modification based on some socio-cultural, political and economic development within Cameroon. Cameroon is a member State of the Bank of Central African States (B.E.A.C.). It is a member of the Central African Economic and Monetary Community (CEMAC). These two bodies, BEAC and CEMAC constitute part of the "Franc Zone". The Franc Zone simply refers to African states whose monetary policy is led by France, notably in the area of the exchange rate and convertibility to foreign currencies, the centralization of international reserves and the harmonization of regulations(Akon). One of the main activities of a commercial bank or financial institution is to provide credit and contribute to the financing of the economy. However, these activities generate a variety of risks, particularly with regard to transformations affecting the financial economy (increased competition, complexity and sophistication of products to meet customer requirements, technological innovations, etc.). In order to identify, measure and control these different risks and to preserve the stability of the banking system, the Basel Committee has in turn set up a system of control and supervision of the risks of banking institutions called Basel I, Basel II and Basel III. The Basel Committee was established in 1974 under the supervision of the G10 countries with the desire of the central banks of the countries that compose it, to improve the stability of the international banking system, the dissemination and promotion of best banking practices and of the international cooperation in prudential supervision(Demirgüç-Kunt \& Detragiache, 2011). As such, it issues recommendations on banking best practices and proposes minimum standards. These recommendations are first incorporated into European regulations in the form of guidelines and then transcribed into the local regulations of each country. Thus, in 1988, the Basel I agreement on international banking regulation, based mainly on the Cooke ratio, defined minimum capital requirements for all outstanding loans granted by a bank. As a result, the Cooke ratio was set at $8 \%$ of risk-weighted assets. Indeed, Basel I requires banks to hold a backing for weighted assets between $8 \%$ and $4 \%$, i.e no less than $8 \%$ total capital and at least $4 \%$ of tier 1 , or core, the capital. Core capital was defined as issued and fully paid ordinary shares/common stock plus non-cumulative perpetual preferred stock and disclosed reserves. Tier 2 which is the supplementary capital is just made of all other capital (Jablecki, 2009). Despite this first step towards stricter regulation of banking activities, Basel I covered only credit risk and did not propose any market and operational risk measures. The emergence of an active market for derivatives and 
structured products from 1996 was one of the main catalysts for a revision of the Basel I regulatory framework. Indeed, the explosive growth of over-the-counter derivatives has resulted in significant off-balance sheet risks not taken into account by this regulatory framework. As a result, and in response to these shortcomings, the Basel Committee published in 2004 a new Basel II regulatory framework.

\section{2- Challenges in the Cameroon's banking sector}

In October 2016, the BEAC established that there are 14 commercial banks in Cameroon with a total of 252 branches spread throughout the country. They include: afriland first bank, atlantic bank Cameroon, United bank for Africa Cameroon, commercial bank of Cameroon, Ecobank Cameroon, Banque International du Cameroun pour l'Epargne et le Crédit (BICEC), Citibank Cameroon SA, Société commerciale de banque Cameroon, société générale des banques au Cameroun (SGBC), Standard Chartered Bank Cameroon, union bank of Cameroon Plc National Financial Credit Bank, BGFI Bank Cameroon, Banque Camerounaise des Petites et Moyennes Entreprises. By august 2017, Cameroon welcomed a new bank which is the Agricultural Community Credit (CCACrédit Communautaire Agricole), that was first a microfinance institution. Today in Cameroon, Afriland First Bank, Société Générale Cameroun and BICEC are leading the banking sector with over $65 \%$ of market shares. Some researchers have stated that banks that perform well in terms of profitability are able to promote the country's economic growth and are able to sustain themselves in an economic recession (ME \& AA, 2017). The challenge facing the Cameroonian banking sector throughout 2017 is the refinancing of government bonds, which the Central bank has also imposed limitations on. This situation resulted in a tightening of liquidity. Fitch also notes that bank resources continue to be short-term. Central government deposits represent only $22 \%$, a level below the average of sub-Saharan African countries(Barth, Caprio, \& Levine, 2004). This situation, from the opinion of some other experts, does not facilitate the achievement of significant long-term financing. Despite these economic challenges, the rating agency is planning some improvements in the Cameroonian banking sector. Overall outstanding loans to the economy are expected to increase between $8 \%$ and $10 \%$ in 2018 . This positive assessment, which is also accompanied by a stable outlook, is based on a set of arguments. The cost of risk is reduced. The outstanding amount of bad debts decreased slightly from $14.1 \%$ by the end of 2016 to only $13 \%$ by August 2017 . This is also a level that is below the average of CEMAC's countries, which oscillates between $15 \%$ and $18 \%$. The other positive fact is that economic growth, although below the government's projections of its 10 -year strategy ending in 2020 (GESP), will be around 4.2\%. Finally, the effective establishment of a credit bureau and the expected launch of a deposit and consignment fund planned for the beginning of 2018, should enhance risk management in the bank system(Triki, Kouki, Dhaou, \& Calice, 2017). But these positive projections still depend on several parameters. The Cameroonian government, in its letter to get a program with the IMF, promised to clean up the banking sector. In particular, it was a question of making a bond loan to absorb certain arrears. Also the strategy of the government of Cameroon to support certain banks in difficulties is not legible(Daumont, Le Gall, \& Leroux, 2004).

\section{3- Afriland First Bank background}

AFRILAND FIRST BANK is a bank approved since 1987. It was ranked 68th in the top 200 of the largest African banks according to the magazine AFRICA REPORT in 2013. Indeed, it was born in the late 80s in following the many bankruptcies of the Cameroonian banking sector due to the economic crisis, under a name totally different from that of today, namely the Caisse Commune d'Epargne et d'Investissement (CCEI); in the 90s, it became CCEI Bank and at the dawn of the second millennium AFRILAND FIRST BANK. It has experienced rather difficult growth, thus coming up against the difficulties of Cameroon's economic and socio-cultural environment. The AFRILAND FIRST BANK bank, commonly known as FIRST BANK, was created in 1987 under the name of CCEI. The economic environment is then characterized by an unfavorable economic situation and the general bankruptcy of the banks. Four observations led to the creation of FIRST BANK: Failure to take into account in the calculation of the Gross Domestic Product (GDP), 60\% of the activity of Cameroonians, since emanating from the informal sector. This sector is nevertheless a source of wealth through its activities, the banking system sidelining the majority of the population living in rural areas, unprepared investors for production, the dominance of the financial system by tontines and usury practices. Only, it is important to note that these observations are also born convictions, certainties to promote the economic emergence of Africa. They are summarized in four axioms: the development of Africa by Africans, economic development through the promotion of entrepreneurship and investment, savings within communities despite poverty, promoting business growth. The main objectives of FIRST BANK are clear: create bridges between the formal and informal sectors, promote the integration of rural people into the banking system, promote the emergence of a class of African entrepreneurs, support existing businesses. These are the four goals that preceded the creation of FIRST BANK. Its promoters have set up specific banking products adapted to the African context. The first branch opened at the current pension agency started working on July 1, 1988. The First Bank currently has about 40 branches in Cameroon but also subsidiaries or offices abroad. 


\section{4- Basel III regulations}

Basel III was issued from the Basel I and Basel II agreements. In fact, it is a regulatory standard for the global bank sector in answer to the crisis by the late 2000s. Indeed, the subprime crisis in 2007 and the sovereign crisis in 2009 have revealed the lack of capital quality and liquidity in global banking system(Manlagnit, 2015). The banking system was neither able to absorb the resulting systemic trading and credit losses nor could it cope with the reintermediation of large off-balance sheet exposures that had built up in the shadow banking sector. After Basel I in the late '98s focused on credit and markets risks through the adoption of the famous Cook ratio, Basel II came in February 2007 to add operational risk to the monitoring system. The crisis of 2008 revealed the flaws of the system and hastened the arrival of Basel III. The new regulation adopted in November 2010 introduced liquidity risk and, in turn, increased solvency. As a result, by November 2010, the Basel Committee on Banking Supervision (BCBS) reformed the agreement package to Basel III in order to improve the ability of the bank system to absorb shocks caused by financial and economic stress, thus reducing the risk of spillover from the financial sector to real economy, to address the lessons of the financial crisis and improve risk management, and governance as well as strengthen bank's transparency and disclosure. In this context, the Basel Committee has proposed raising the capital requirements:

$>$ Common Equity Tier 1 (Core Tier 1): increase of the Core Tier One ratio from 2\% to 4.5\%, integration of an additional 2.5\% safety mattress (buffer) horizon 2019, hard equity level increased to $7 \%$ by 2019 .

$>$ Implications for banks: Retention of profits and limitation of dividend distributions to meet additional capital requirements, targeting a $9 \%$ level for the Core Tier One ratio to facilitate the management of distribution policy in times of stress, incentive to separate from certain assets consuming equity (eg minority equity securities), implementation of a capital management policy to achieve a solvency ratio in the medium term between $13 \%$ and $15 \%$.

In summary, the Basel III prudential framework focuses on three pillars: the minimum capital requirements (pillar 1), the process of prudential supervision (pillar 2), and the market discipline (pillar 3). Indeed, the new agreement introduced two new liquidity ratios:

$>$ LCR (Liquidity Coverage Ratio or Liquidity Coverage Ratio) promotes the short-term resilience of a bank's liquidity risk profile through high quality assets that can withstand a one-month crisis;

$>$ The NSFR (Net Stable Funding Ratio). This ratio promotes longer term resilience. The idea is that bank jobs are financed by structurally stable resources by reducing the risk of maturity transformation.

Our study will then focus on analyzing Core Tier 1 and those two liquidity ratios impact's on AFB.

\section{Literature review}

Basel II is an end result of efforts toward more risk-sensitive capital adequacy measures in the banking industry (Tiryaki, 2011). Proposed in 2004 by the Basel Committee, Basel II accords are more comprehensive and define a more relevant measure of risk(Beltratti \& Paladino, 2016). This new regulatory framework is essentially based on 3 pillars for a best understanding on banking risks. According to the first pillar, banks' own funds must represent at least $8 \%$ of the credits they have granted. This level remains unchanged from the first agreement, but its calculation has been considerably sophisticated since it takes into account the credit risk. The less risky a loan is, the less the bank has to cover in equity, and vice versa. These weightings of the risks go initially to be done according to a so-called standardized method. In late 2007, internal methods, after approval by the supervisory authorities, may be used. The second pillar tells banks to value the adequacy of their capital level with the risks to which they are exposed. The supervisory authorities must supervise this work of the banks. The third pillar sets standards for the publication of banks' financial information, both on their own funds amount, their risk profile and their capital adequacy. This transparency, in accordance with the Basel Committee, should be an incentive to respect the new agreement(Decamps, Rochet, \& Roger, 2004). We are witnessing a restructuring and above all an unprecedented concentration of the global financial system and Basel III regulation is speeding up this process. In the United States, we went from 13,822 commercial banks by June 1987, to 4,982 at late June 2017, or 8,840 disappearances, a reduction of $63 \%$ in 30 years(Ly, Chen, Wang, \& Jiang, 2017). However, the most important costs of setting up Basel III do not only concern capital -13\% - but also market risks $-30 \%$. SIA Conseil's worksite breakdown thus advances the following figures: market risk, 30\%; counterparty risk, 23\%; stress tests, 17\%; own funds, 13\%; liquidity ratios, 12\%; and remuneration, 5\%. However, African SME (Small and Medium-sized Enterprises) have financing needs estimated by the ADB at $\$ 135$ billion. Faced with restructuring and the decline in liquidity, African banks will not be capable to cope and it is the development of Africa that will be impacted(Triki et al., 2017). SMEs account for about $90 \%$ of global economic activity. The solution may be to significantly strengthen the African Guarantee Fund for SME launched in 2011 by ADB (African Development Bank). In a recent briefing on the banking system in several countries, Fitch rating agency Ratings reports that the outstanding loans granted by Cameroonian commercial banks grew by $7.6 \%$ over the twelve-month period late of August 2017. For this country, it is just an increase of over 231 billion CFA francs, based on data on bank credit consulted by the Ecofin Agency. Given the financing needs of the Cameroonian economy, such a 12-month 
advance may seem weak, but it occurs in a difficult context. A sizeable segment of the loans granted by these banks is the financing of foreign trade, especially imports, which supplies $70 \%$ of the local markets with consumer products. For this, commercial banks need access to the Forex (Foreign Exchange) reserves that are centralized at BEAC level. However, access to these FOREX reserves was made difficult over the period, due to the limitations imposed, so as to uphold the external steadiness of the currency (CFA Francs), which had worsened sharply in 2016. In this context, the commercial banks had no choice but to finance each other, so the rates of advances in foreign currency on the interbank market exceeded by $30 \%$ the official average served by the BEAC at late September. With Basel III, the entire business model of banks must be redesigned, a consequence of an unprecedented decline in standard of profitability of banks(Hong, Huang, \& $\mathrm{Wu}, 2014$ ). Regarding the consequences, one could refer to the many studies that almost all go in the right direction, minimizing the Basel III's impact like the 2010 study by Weber. The Macroeconomic Assessment Group (MAG) and the Long-term Economic Impact Group (LEI) studies put forward a precise figure: GDP will fall by around $0.19 \%$ for each $1 \%$ point increase in the capital ratio banks. But experience teaches us to be wary of all these studies not to mention the report of the Institute of International Finance (IIF) which denounces a significant impact on the world's economy with the loss of 3 growth points. It is necessary to distinguish between the direct impact on financial organizations and the indirect impact that the real economy will bear for lack of funding. For the bank system, a comprehensive study of the impacts is of no interest since, as (Kashyap, Stein, \& Hanson, 2010) shows, "wellcapitalized banks face a much lower cost of capital". Moreover, Switzerland - the great country of the banks - went into rebellion by asking for relaxed rules for regional institutions. The implementation of Basel III causes huge problems in terms of profitability and business model(Dermine, 2015). With the control's increase, shadow banking has emerged in a reckless way. Based on CFS, it would weigh 150\% of global GDP, with 92 trillion dollars. The problem comes from our economies that are literally undergoing debt infusions.

\section{Methodology and data}

The dataset used in this study is secondary data, from the World Bank. In fact, in 2010 the World Bank launched its Open Data initiative to internet users. Data collection by the World Bank is carried out by recognized international sources and depicts current, accurate data and estimates for different regions and countries. The mission of the World Bank Development Data Group is to provide high quality national and international statistics to clients inside and outside the Bank and to improve the capacity of member countries to produce and maintain use statistical information. In addition, World Bank databases are essential tools to support critical management decisions and provide statistical information essential to the Bank's operational activities. The application of internationally accepted standards results in a source of information that is both consistent and reliable. We rely on secondary data believing that it helps us to gain insight into both the methodologies and statistical methods, and optimize the quality of our research.

The model for estimation follows the econometric equation by defining the level of the regulations and how these regulations affect AFRILAND FIRST BANK.

$B 3=\operatorname{Cet} 1+\operatorname{Cet} 2+\operatorname{Cet} 3$

$A F B=\alpha_{\mathrm{o}}+\alpha_{1} B 3 \sum(\operatorname{Cet} 1+\operatorname{Cet} 2+\operatorname{Cet} 3)+\varepsilon_{\mathrm{i}}$

With:

Cet $1=$ common equity 1 ;

Cet $2=$ liquidity coverage ratio;

Cet $3=$ net stable funding ration

\section{$7 \quad$ Results and discussion}

Table 1.1. unit root test using Augmented Dickey-Fuller

\begin{tabular}{|c|c|c|c|}
\hline & & t-statistic & Prob.* \\
\hline \multicolumn{2}{|c|}{ Augmented Dickey-Fuller test statistic } & -12.13372 & 0.0000 \\
\hline \multirow[t]{3}{*}{ Test critical values } & $1 \%$ level & -3.555023 & \\
\hline & $5 \%$ level & -2.915522 & \\
\hline & $10 \%$ level & -2.595565 & \\
\hline
\end{tabular}

Table 1 shows that there is a unit root running through the data and it is stationary. And the negative value of the test statistic means that the model will valid and is globally accepted. 
Table 1.2 regression result

\begin{tabular}{|c|cccc|}
\hline Variable & Coefficient & Std. Error & t-Statistic & Prob. \\
\hline Cet1 & 0.0502804 & 0.0060542 & 8.31 & 0.0000 \\
Cet2 & -0.0492457 & 0.0041938 & -11.74 & 0.0000 \\
Cet3 & 0.1230771 & 0.0325283 & 3.78 & 0.0000 \\
Cons. & 2.162314 & 0.4582008 & 4.72 & 0.0000 \\
& & & & \\
R-squared & 0.7974 & & & \\
Adjusted R-squared & 0.7857 & & & \\
Durbin-Watson stat & 0.858389 & & & \\
Prob(F-statistic) & 0.000 & & & \\
\hline
\end{tabular}

From table 2 where we analyze the impacts of Basel III regulations on AFB, we can consider from the results we obtain that: Cet 1 has a positive effect of $8.31 \%$ on AFB; AFB can easily improve the quality of the hard core of its capital, Core Tier 1, by allocating more and better capital to riskier activities. In that case the banks' solvency would be increased. Cet 2 has a negative effect of $11.74 \%$ on AFB; the liquidity coverage ratio applies to all banking institutions that have more than $\$ 250$ billion in total consolidated assets or more than $\$ 10$ billion in onbalance sheet foreign exposure. Banks are required to have a $100 \%$ LCR, which means holding an amount of highly liquid assets that are equal to or greater than its net cash flow over a 30-day stress period. Highly liquid assets can include cash, Treasury bonds or corporate debt. From that point of view, we can clearly note that AFB cannot fulfill this criterion since its total balance sheet at the end of 2017 was $\$ 1.51$ billion. Cet 3 has a positive effect of $3.78 \%$ on the bank.

Regarding the Basel III agreements, generally in Cameroon, banks face potential borrowers quite risky due to the banking system opacity. This opacity is supported by the non-negligible weight of the informal sector that contributes between 20 and 30\% to the formation of the country's GDP, as in South Africa according to a report by the IMF. The lack of information on loan applicants is an essential element that reduces the lending activity of banks and especially that requires high interest rates. In addition, there is no important structure that can increase the incentive for banks to lend. In developed countries, for example, there are structures that support the unemployed (such as employment pole in France). These structures guarantee an income stream for workers in the event of job loss, thus reducing the risk of default when these workers wish to have a loan. Their absence in Cameroon does not facilitate the establishment of credits from banks. From Basle I to Basel III, the Basel Committee for Banking Supervision (CBSB) agreements reflect the evolution of financial markets, the need to better understand and integrate risks. It is true that the Basel I agreements were soon confronted with the evolution of the financial markets and the much greater market risks, but the ratification of Basel I allowed the establishment of minimum standards for the coverage of credit risk. In Basel I agreement, Tier 1 capital is a minimum of $4 \%$ ownership equity but investors generally require a ratio of $10 \%$. Tier 1 capital should be greater than $150 \%$ of the minimum requirement.

The theoretical reason for holding capital is that it should provide protection against unexpected losses. This is not the same as expected losses, which are covered by provisions, reserves and current year profits. Tier 1 capital is the core measure of a bank's financial strength from a regulator's point of view. It is composed of core capital which consists primarily of common stock and disclosed reserves (or retained earnings), but may also include nonredeemable non-cumulative preferred stock. The Basel Committee also observed that banks have used innovative instruments over the years to generate Tier 1 capital; these are subject to stringent conditions and are limited to a maximum of $15 \%$ of total Tier 1 capital. This part of the Tier 1 capital will be phased out during the implementation of Basel III. It is expected that all banks should meet the minimum required CET1 ratio of $4.50 \%$ by 2019 . From the above results, we can confirm that AFB can easily apply that standard of Basel III in their system which was formulated to prevent the bank for a crisis(Kasekende, Bagyenda, \& Brownbridge, 2012).

\section{Conclusion}

From the third quarter of 2007 to the second quarter of 2009, the world was hit by one of the most severe economic crises in its history, following the production crisis of 1929. This crisis revealed several shortcomings in the economy management of bank liquidity by the economy. Thus, in order to strengthen and ensure a sound financial system, the Basel Committee on Banking Supervision (BCBS) established in 2010, under the Basel III agreements, two liquidity standards, namely: the liquidity ratio short-term and long-term (LCR) and long-term structural liquidity ratio (NSFR)These ratios have come into effect gradually since 2015 and must be fully applied in 2018 for the structural liquidity ratio and in 2019 for the short-term liquidity ratio. Basel III and Basel II thus only take into account the risks that already exist, while in the first Basel agreements, standard risks (credit risk, market risk, etc.) were naturally integrated. The first two agreements are mainly part of a micro-prudential framework: Basel I is best known for the Cooke ratio, even though the recommendations of the Basel Committee on Banking 
Supervision are much broader while Basel II introduces three pillars aimed at fully cover the banking risk and promote the use of internal risk management models. The systemic risk and procyclicality revealed by the subprime crisis led the Basel Committee on Banking Supervision to formulate Basel III in a micro and macroprudential framework.Basel III is a big reform that touches on supervision, regulation and crisis management. It has a very strong technical and political aspect. This reform only makes sense if it is implemented with social dialogue. This Basel III approach aims to strike the right balance between the stability of the financial system and the pursuit of growth. This new balance will have an immediate cost but expected future benefits. To comply with regulatory standards, AFB should therefore strengthen its capitalization and change the structure of its balance sheet in order to improve the liquidity of its assets and the stability of its financing. The Basel III agreement provides for the establishment of a regulatory leverage ratio, in addition to the risk-weighted capital ratio, concomitant with the liquidity ratios. By contrast, most African countries, and in particular Cameroon, have not yet adopted these liquidity standards. According to a report published in 2015 by Finafrique, Cameroon is still migrating to Basel II, while Nigeria complies with Basel II standards. Nevertheless, these countries aspire to the application of Basel III.

The Basel III standard aims to strengthen the requirements from the Basel II standard on bank's minimum capital ratios. In addition, it introduces requirements on liquid asset holdings and funding stability, thereby seeking to mitigate the risk of a run on the bank. According to the results obtained above, it appears that the Basel III agreements would have a quite positive effect on Afriland First Bank. In reading the various agreements, it is possible to note, in addition to the move towards a macroprudential framework, a modification of the taking into account of the financial risks. In reading the precarious situation of the Cameroonian financial system, it is worth noting that it is not fully developed and the absence of a dynamic credit market hinders more dynamic economic growth. Most analysts see opportunities for growth in the supply of financial services to the unbanked and in exploiting the potential of the vast informal sector. We thus conclude by saying that the implementation of Basel III agreements in Afriland First Bank's banking activity, should be revised in line with the economic and sociocultural context of Cameroon. At the end of this study, it emerges that the common equity Core Tier 1 and the NSFR are adequate for Afriland First Bank's banking activity. Afriland First Bank should focus even more on the micro-prudential aspect before venturing into the macroprudential side of the Basel III agreement. In addition, it would be beneficial to think of typically African Basel agreements, looking a little more at the developing economies of most African countries.

\section{References}

Akon, G. A critical look at banking sector regulations in Cameroon: Retrieved.

Barth, J. R., Caprio, G., \& Levine, R. (2004). Bank regulation and supervision: what works best? Journal of Financial intermediation, 13(2), 205-248. doi: https://doi.org/10.1016/j.jfi.2003.06.002

Beltratti, A., \& Paladino, G. (2016). Basel II and regulatory arbitrage. Evidence from financial crises. Journal of Empirical Finance, 39, 180-196. doi: https://doi.org/10.1016/j.jempfin.2016.02.006

Daumont, R., Le Gall, F., \& Leroux, F. (2004). Banking in Sub-Saharan Africa: what went wrong? : International Monetary Fund.

Decamps, J.-P., Rochet, J.-C., \& Roger, B. t. (2004). The three pillars of Basel II: optimizing the mix. Journal of Financial intermediation, 13(2), 132-155. doi: https://doi.org/10.1016/j.jfi.2003.06.003

Demirgüç-Kunt, A., \& Detragiache, E. (2011). Basel Core Principles and bank soundness: Does compliance matter? Journal of Financial Stability, 7(4), 179-190. doi: https://doi.org/10.1016/j.jfs.2010.03.003

Dermine, J. (2015). Basel III leverage ratio requirement and the probability of bank runs. Journal of Banking \& Finance, 53, 266-277. doi: https://doi.org/10.1016/j.jbankfin.2014.12.007

Hong, H., Huang, J.-Z., \& Wu, D. (2014). The information content of Basel III liquidity risk measures. Journal of Financial Stability, 15, 91-111. doi: https://doi.org/10.1016/j.jfs.2014.09.003

Kasekende, L., Bagyenda, J., \& Brownbridge, M. (2012). Basel III and the global reform of financial regulation: how should Africa respond? a bank regulator's perspective. Bank of Uganda mimeo.

Ly, K. C., Chen, Z., Wang, S., \& Jiang, Y. (2017). The Basel III net stable funding ratio adjustment speed and systemic risk. Research in International Business and Finance, 39, 169-182. doi: https://doi.org/10.1016/j.ribaf.2016.07.031

Manlagnit, M. C. V. (2015). Basel regulations and banks' efficiency: The case of the Philippines. Journal of Asian Economics, 39, 72-85.

Naceur, S. B., Marton, K., \& Roulet, C. (2018). Basel III and Bank-Lending: Evidence from the United States and Europe. Journal of Financial Stability.

Ozili, P. K., \& Outa, E. (2017). Bank loan loss provisions research: A review. Borsa Istanbul Review, 17(3), 144163. doi: https://doi.org/10.1016/j.bir.2017.05.001

Rubio, M., \& Carrasco-Gallego, J. A. (2016). The new financial regulation in Basel III and monetary policy: A macroprudential approach. Journal of Financial Stability, 26, 294-305.

Saab, S. Y., \& Vacher, J. (2007). Banking sector integration and competition in CEMAC: International Monetary 
Fund.

Schmaltz, C., Pokutta, S., Heidorn, T., \& Andrae, S. (2014). How to make regulators and shareholders happy under Basel III. Journal of Banking \& Finance, 46, 311-325. doi: https://doi.org/10.1016/j.jbankfin.2014.05.031

Triki, T., Kouki, I., Dhaou, M. B., \& Calice, P. (2017). Bank regulation and efficiency: What works for Africa? Research in International Business and Finance, 39, 183-205. doi: https://doi.org/10.1016/j.ribaf.2016.07.027 